\title{
Magnet Structural Support Design Guidelines
}

Christine Ader, Michael McGee, and Robert Reilly

January 5, 2017

This manuscript has been authored by Fermi Research Alliance, LLC under Contract No. DE-AC02-07CH11359 with the U.S. Department of Energy, Office of Science, Office of High Energy Physics. 


\section{TABLE OF CONTENTS}

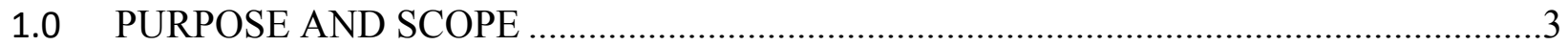

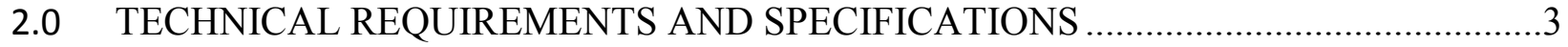

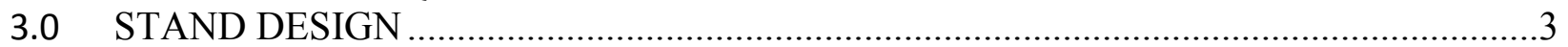

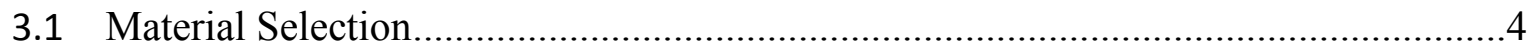

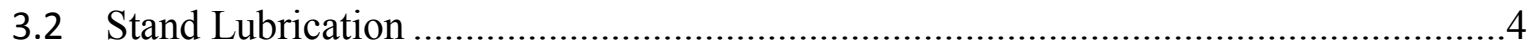

3.3 Blind Threaded or ACME Holes for Vertical Support...........................................5

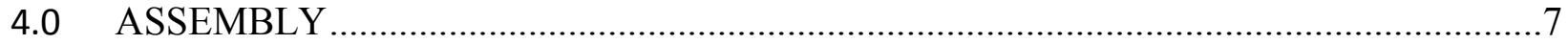

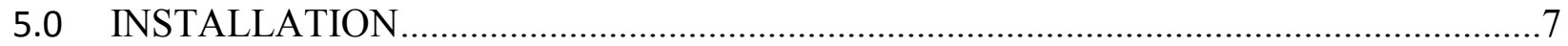

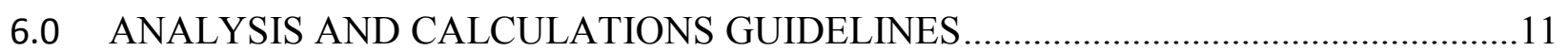




\subsection{Purpose and Scope}

Structural supports are widely used at Fermilab typically to hold up magnets, instrumentation, and other devices for the accelerators. This document is intended for engineers, designers and technical staff and attempts to capture some of the lessons learned and also to assist future work. Although the document is comprehensive, it does not cover everything and is meant as a guideline.

\subsection{Technical Requirements and Specifications}

The project should provide specifications for required stand such as the tolerances, weight of device, etc. The project or FESS should also provide specifications which include the location within the enclosure, roll and pitch angles if significant, floor and ceiling height, possible wall interferences, piping and cable tray interferences, etc. The information provided should include magnet type, magnet orientation (the electrical buss connections may impact the design), motorized versus non-motorized stand, and alignment tolerances.

Alignment tolerances horizontally and vertically are typically 5 to 10 mils, most often $0.25 \mathrm{~mm}$ (10 mils) for accelerators. For stationing (along the Z-axis), the tolerances are typically 100 to 200 mills. The transfer lines and single pass accelerator beam-lines are typically less stringent than circulating beam-lines.

\subsection{Stand Design}

Three-point adjustment on four-leg stands should be used, unless there is a good reason that a single adjuster cannot be used on one end, such as a Lambertson or other unique magnet, in which a 4-point stand could be used. Three-point stands are preferred for more accurate alignment, since for a 4-point stand, the weight distribution shifts among the four points as the magnet is adjusted. For calculations on a 4-point stand, assume that the load is distributed on only 2 points. Be cautious of over-constraining 4-point stands.

An unconstrained single-point adjuster, especially if taller than it footprint, if it fails to slide or roll on its base, can be a tipping hazard during a horizontal adjustment. Vertical adjustment range should be limited to two inches, and the base should be as large as the overall height of the adjuster.

When considering the reuse of any stand design, determine if old engineering notes exist and/or if a new engineering note should be written and/or if the design is robust and/or functional. Do not assume functionality or strength of old design is adequate without analysis and review. A formal Engineering Note is not required for every stand, nor every family of stands, but informal notes on structural analysis should be recorded and permanently retained in an accessible form. 
For ceiling mounted stands, steel re-bar and embedded channel is often encountered, which may interfere with the installation of concrete anchors, so if possible, provide extra holes for the concrete anchors. The design engineer should always specify the minimum number required. Another option is to have pre-drilled tabs fabricated which can be welded on the stand if there are interference issues. Any stands that get installed in ceiling must meet the installation procedure requirements in FESHM 7080 Concrete Anchor Devices.

The usual preference when installing stands is to drill for anchors directly through the stand feet. Holes in the stand feet should be far enough away from the upright verticals in order to get the Hilti hammer drill in (typically 2 to $\left.3^{\prime \prime}\right)$. There is a 2 " radius from the bit to the drill motor.

Round holes are preferred, but in some cases if the exact position of the stand is uncertain or not attainable due to interferences, slots may be used. Slots should be perpendicular to the beam direction.

- For $1 / 2$ " Hilti drop-ins, the holes should be $11 / 16^{\prime \prime}$.

- For 5/8" Hilti drop-ins, the holes should be 29/32"

- For the $1 / 2$ " Hilti Kwik-bolts, the holes should be 9/16.

These numbers would apply to either holes or slots. All the numbers are $1 / 16^{\prime \prime}$ oversized from the drill per the Hilti Technical Guide.

Vertical adjustment should either have a hard stop or provide that the end of adjustment threads are visible.

For a very tall stand, either the legs should be angled, or cross bracing should be provided, for structural truss triangulation, as was done on MiniBooNE B872 and Q874-875.

If a magnet traps another magnet, provide that the first magnet can be removed and the supporting members can be removed easily in order to change the second magnet, as was done on NUMI and ANU extraction.

If a magnet spans a change in floor level, it is generally better to support the magnet on two stands, one on each level, but provide the means to install this magnet, such as sideways moving rollers as was done on NuMl extraction.

For small stands, the base plate should be one unit or pairs of feet attached to each other in order to maintain square-ness and parallelism, as long as it does not create a binding situation.

Do not put two large magnets on one stand or tied on one stand. This was done for the B2 magnets for NuMI and were very difficult to align.

Consider how the magnet will be installed before finalizing the design. (mono-rail, Hillman rollers, Elwell, Rico Forklift, etc). Have assembly drawings which include installation steps shown. This will help to mitigate installation interferences.

In terms of support stability, an engineer should consider a tipping or seismic analysis. 
Motorized stands should have hard stops and/or limit switches in order to prevent motion beyond the intended design and/or limit switches.

For magnets at severe angles, forklift lifting pads or saddles may be needed. Consider whether there is a need for forklift lifting points or pads to be incorporated as a permanent part of the stand. If so, measure the actual forks and do not rely on drawings.

Stand weldments should be designed to be symmetrical if possible. This will mitigate any issues of having to turn the stand around in the tunnel if it is a larger stand and the tunnel is small and the stand is brought down in the wrong orientation.

\subsection{Material Selection}

The type of steel selected may impact magnetic fields so the machine physicists should be consulted regarding these potential issues. Additionally, the environmental conditions should

be understood. For example, the links of grade 100 alloy steel chain failed while supporting the 23-ton steel modules in the MiniBooNE 25-meter absorber in 2007. The failure report notes a threshold hardness of $35 \mathrm{Rc}$ (UTS of about $160 \mathrm{ksi}$ ) for the potential of hydrogen cracking. Note that this was in a severe high humidity, nitric acid environment that was also stagnant. In the severe target hall environments try to use 316SS bolts where high ultimate strength is not required, and use grade 5 titanium where a high strength fastener is needed. For the NuMI target hall, grade 8 bolts are not recommended for a new installation.

\subsection{Stand Lubrication}

Sliding surfaces should never be painted. The coefficient of friction of paint is high so the stand may not slide well, and the paint could also gall or gum up. SAE or UN threaded and acme threaded rod and holes should never be painted.

For sliding surface, use Multifil 426 bearing tape (this replaced Glacier Plate, Garlock DU Flat Group 2 material due to lead content) which can be cut and put between two metal surfaces to reduce the coefficient of friction. Please note that water will bead-up on the bearing side, while the bonding side will appear wet. So it is critical to note the orientation in which the tape is placed. Another option is to use powder coat for sliding surfaces. This will have to be determined during the design phase. If stands are made from Aluminum, the sliding surfaces can be dicronited to reduce the coefficient of friction and create a much better sliding surface.

Threaded parts could be greased with radiation resistant grease, but grease attracts dirt which can cause long-term problems. Threaded parts can be coated (zinc-chromate is commonly specified) to eliminate the need for grease. Radiation resistant greases that have been used include Lubriplate or Chesterton 622 White Grease. Verify with ES\&H that the lubricant can be used in radiation environments since there are always concerns about mixed waste. (This is 
specifically why 622 white grease was used in the MI/RR tunnel. It is a food grade grease that has been approved by ESH\&Q as to not cause a mixed waste if it becomes radioactive)

\subsection{Blind Threaded or ACME Holes for Vertical Support}

Blind holes, either SAE threaded or ACME, used for vertical support is a serious safety concern. If the vertical support rod is turned to install or align the magnet (to raise or lower), the rigging or Alignment crew has no way to know when the rod is going to screw out of the nut, with the danger that the magnet could fall. There have been two such incidents in the Main Ring and Switchyard.

One should be able to see the end of the threaded rod, or it should be captured. If possible, drilling sight holes should be considered for existing blind holes.

With the big ACME stands for Main Injector, the bottom of the nut was counter-bored and then a disc screwed to the bottom of the threaded stud, which acted as a "stop" preventing the stud from ever coming out of the nut. Here is a drawing of that assembly:

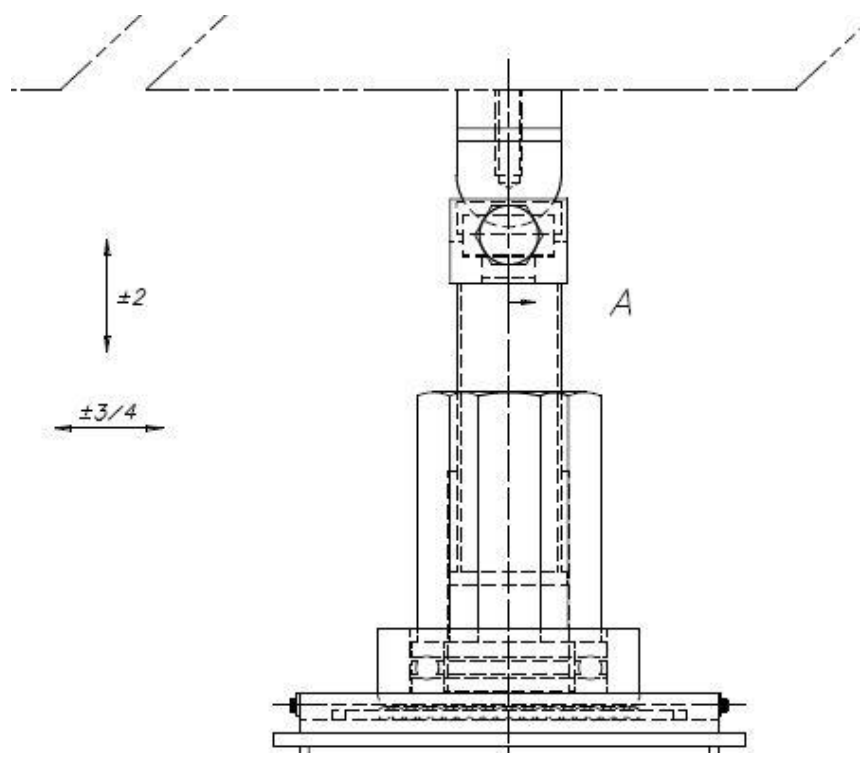

If re-using old stands, consider hard mechanical stops, either a stop on the stand or on the device or chains to limit the amount of travel, with the appropriate signage. Both ends of the magnet should have these stops or signage.

Even with signage, there is nothing preventing from someone from accidently unthreading the magnet. At N01/M01, someone has been injured because of this issue. Here is the signage on the N01/M01 magnets which became unthreaded, despite the signage: 

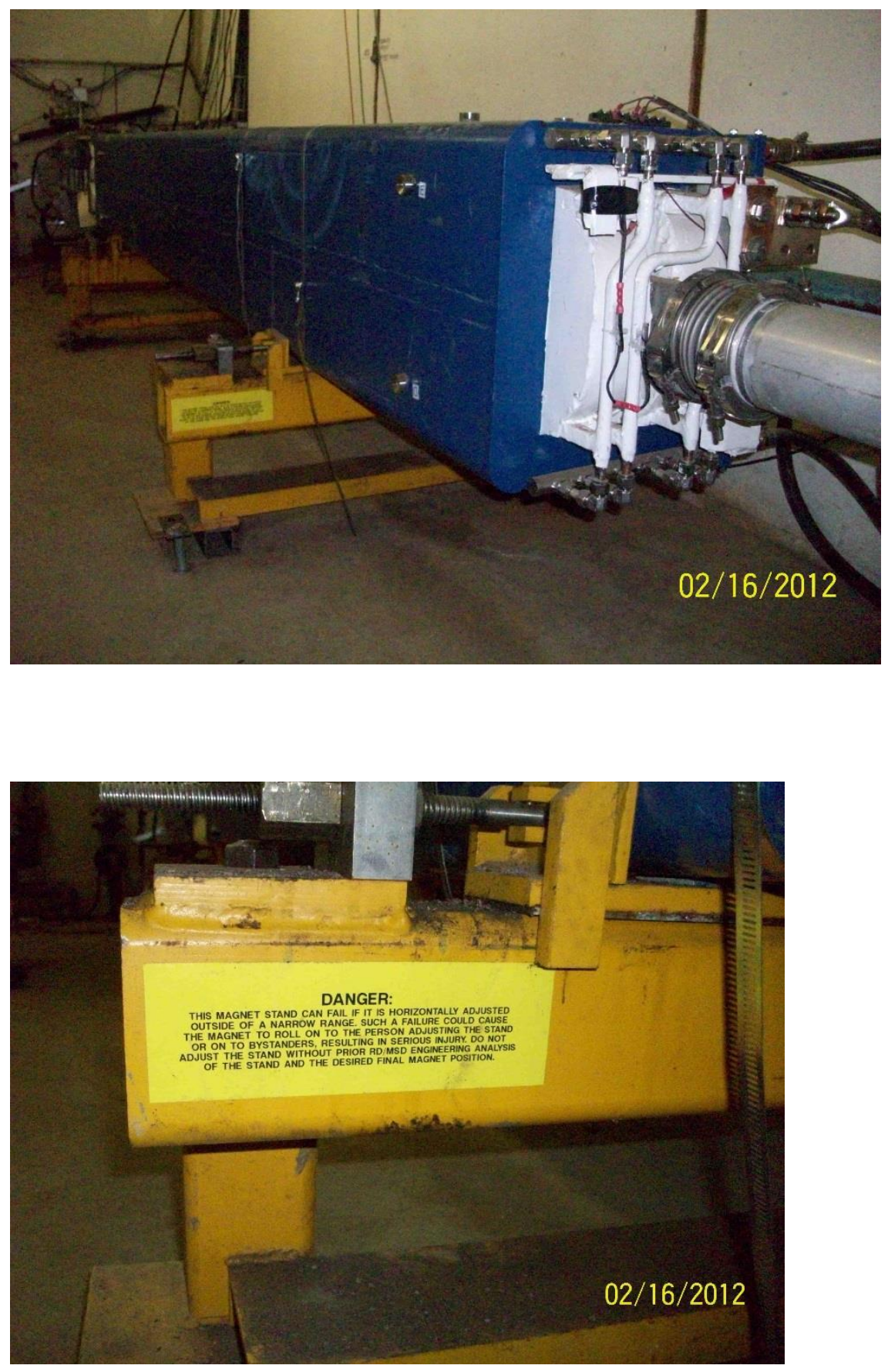

\subsection{Assembly}

Stand Quality Control (QC):

- Check unassembled parts to print

- After assembly, check overall dimensions

- Check all adjustors for free movement and full range of motion 
- Lubricate threads with radiation resistant grease such as Lubriplate or Chesterton 622 White Grease if needed. Do not paint sliding surfaces or threads.

- Verify with the engineer that QC has been completed before taking any stand parts or assemblies downstairs.

- If problems with any of the above are discovered, contact the Project Engineer for resolution.

\subsection{Installation}

Consider having templates for stand layouts made of aluminum or even cardboard. However, riggers and technicians often prefer to use the stand itself to use to use to drill the holes since the drill bit can walk or jump during hammer drilling, and the heavy stand prevents this problem. Aluminum templates can be made using drill bushings, which actually can in some cases be better than using the stand itself. This was done for Main Injector where the spacing between pairs of stands was critical. It makes the job go quicker and holds the tolerances very well. One option to use with a template is a smaller pilot drill without a hammer drill to ensure that the hole is not drilled at an angle. Then use a hammer drill for the final hole. This is not necessary if the template has drill bushings.

Rebar is typically $3 / 4$ " thick and has a spacing of 8 " in tunnel hoops and 12 " spacing for cast in place. This information will be specified on the FESS drawing but should not be counted on. The concrete strength can be assumed to be 3,000 psi for base material and 5,000 psi for shield blocks. If greater strength is needed for a design, check with a FESS engineer for the actual strengths. The Hilti PS-50 Scanner can scan to a depth of 4.72" and costs about $\$ 1500$.

Rebar must be scanned prior to drilling concrete and hanging stands to allow for modifications if necessary. It has all of the specifics of how to scan, drill, set Hilti's and what types of anchors to use for different applications, as well as load-testing requirements.

Unistrut embedments should be used if possible (see information below). Check with FESS for specifications and load ratings.

For unusual installations or with stands with not much vertical adjustment, one may want to consider mapping the floor or ceiling with survey's assistance to understand the straightness of the concrete.

Spalling concrete and old hilti holes are common in old tunnel enclosures. Additionally, old enclosure walls can have a significant angle (recently a wall was measured with a slope of about 3 degrees). Be aware that the concrete will probably not be uniform and perfect. Even with new construction, concrete walls and floors are usually not level. Variations of $+/-1.5$ inches in the level of floors in brand new buildings have been seen. 
For some installations, the magnet must be lifted and temporarily supported, then the stand moved into place, then the magnet set on the stand. Provide clearance to move the stand in and out.

For magnets installed at a significant angle, provide angled fork adapters or other means of lifting the magnet into place and removing it at an angle, as was done on Muon Abort ABV2.

For magnets installed by means of trolleys or rails or roller skates, provide that the installation rails are structurally sound throughout the travel, and that the magnet can be set on and removed from the rail system by fork lift or magnet mover or chain falls or hydraulic lift table, as was done on NUMI Q106.

Concrete inserts:

Below is a catalog cut indicating the capacity of Unistrut P3200 series concrete inserts. As shown in attached data sheet, the allowable capacity for unistrut P3200 series inserts varies depending on the continuous length of the embedment.

The Main Injector specified Unistrut P3200 series or Elcen Metal Products Figure 1150 concrete inserts in the general notes. No load capacity was found for the Elcen concrete inserts. Assume the concrete inserts for Main Injector were Unistrut P3200 series. Unistrut P3200 series is also specified in the Mu2e drawings. 


\section{MEDIUM DUTY}

\section{P3200 SERIES - $15 / 8 " \times 13 / 8 "$}

\section{P3249 thru P3252}

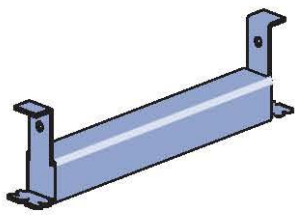

"NC" Suffix - No Closure Strip, With End Caps "WC" Suffix - With Closure Strip \& End Caps

P3253

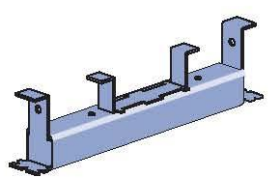

"NC" Suffix - No Closure Strip, With End Caps \& Back Plates "WC" Suffix - With Closure Strip, End Caps \& Back Plates

\section{P3254 thru P3270}

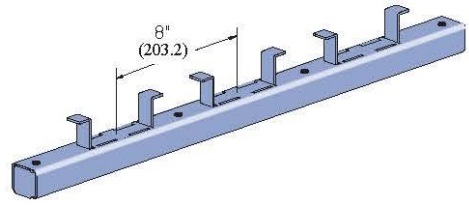

"NC" Suffix - No Closure Strip, W/End Caps \& Back Plates "WC" Suffix - WClosure Strip, End Caps \& Back Plates "X" - No Closure Strip, No End Caps, W/Back Plates
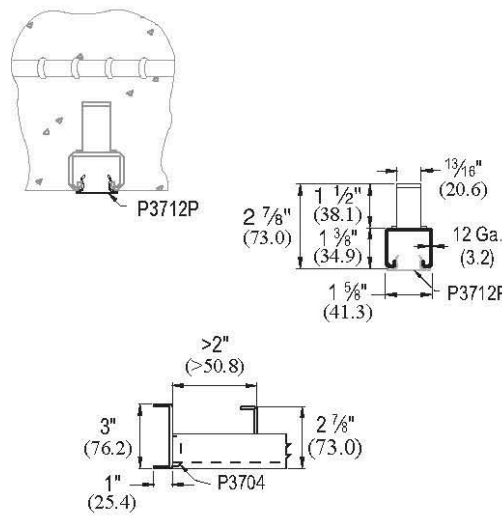

\section{FEATURES AND BENEFITS}

- Includes closure and end caps unless otherwise requested

- P3280 end cap used when distance to first anchor is up to 2" (51 mm)

- P3704 end cap is used when end distance to first anchor is over 2" (51 mm)

- Nail or anchor inserts to forms every 16" (406.4 mm) to 24 " (609.6 mm)

- Anchors are 8" (203.2 mm) on center

- Material: Cold formed from 12 Ga. (3) steel conforming to ASTM A1011 SS GR 33 or ASTM A653 GR 33. A. Stainless steel available on special order

- Finish: Choice of hot-dipped galvanized (HG) conforming to ASTM A123 or A153, or pre-galvanized (PG) conforming to ASTM A653-G90

\begin{tabular}{|c|c|c|c|c|c|c|}
\hline $\begin{array}{c}\text { Part } \\
\text { Number }\end{array}$ & $\begin{array}{c}\text { Insert } \\
\text { Length } \\
\text { In/Ft (mm) }\end{array}$ & $\begin{array}{c}\text { Wt/100 } \\
\text { pcs } \\
\text { Lbs (kg) }\end{array}$ & $\begin{array}{l}\text { Max. Allowable } \\
\text { Point Load } \\
\text { Lbs (kN) }\end{array}$ & $\begin{array}{l}\text { Min. Spacing } \\
\text { of Pt. Loads } \\
\text { In }(\mathrm{mm})\end{array}$ & \multicolumn{2}{|c|}{$\begin{array}{l}\text { Max. Allowable } \\
\text { Uniform Load } \\
\text { Lbs (kN) }\end{array}$} \\
\hline P3249 & $\begin{array}{c}3^{\prime \prime} \\
76.2\end{array}$ & $\begin{array}{l}85 \\
39\end{array}$ & $\begin{array}{l}500 \\
2.22\end{array}$ & - & $\begin{array}{l}500 \\
2.22\end{array}$ & \\
\hline P3250 & $\begin{array}{c}4^{\prime \prime} \\
101.6\end{array}$ & $\begin{array}{l}100 \\
45\end{array}$ & $\begin{array}{l}800 \\
3.56\end{array}$ & - & $\begin{array}{l}800 \\
3.56\end{array}$ & \\
\hline P3251 & $\begin{array}{c}6^{\prime \prime} \\
152.4\end{array}$ & $\begin{array}{c}130 \\
59\end{array}$ & $\begin{array}{l}1,000 \\
4,45\end{array}$ & - & $\begin{array}{l}1,000 \\
4.45\end{array}$ & \\
\hline P3252 & $\begin{array}{c}8^{\prime \prime} \\
203.2\end{array}$ & $\begin{array}{l}159 \\
72\end{array}$ & $\begin{array}{l}1,200 \\
5.34\end{array}$ & - & $\begin{array}{l}1,200 \\
5.34\end{array}$ & \\
\hline P3253 & $\begin{array}{c}12^{\prime \prime} \\
304.8\end{array}$ & $\begin{array}{l}227 \\
103\end{array}$ & $\begin{array}{c}2,000 \\
8,90\end{array}$ & - & $\begin{array}{c}2,000 \\
890\end{array}$ & \\
\hline P3254 & $\begin{array}{c}16^{\prime \prime} \\
406.4\end{array}$ & $\begin{array}{l}270 \\
122\end{array}$ & $\begin{array}{c}2,000 \\
8,90\end{array}$ & $\begin{array}{c}12 \\
304.8\end{array}$ & $\begin{array}{l}4,000 \\
17,79\end{array}$ & \\
\hline P3255 & $\begin{array}{c}20 " 1 \\
5080\end{array}$ & $\begin{array}{l}357 \\
162\end{array}$ & $\begin{array}{c}2,000 \\
890\end{array}$ & $\begin{array}{c}12 \\
304.8\end{array}$ & $\begin{array}{l}4,000 \\
17,79\end{array}$ & \\
\hline P3256 & $\begin{array}{c}24 " \\
609.6\end{array}$ & $\begin{array}{l}399 \\
181 \\
\end{array}$ & $\begin{array}{c}2,000 \\
8,90\end{array}$ & $\begin{array}{c}12 \\
304,8 \\
\end{array}$ & $\begin{array}{l}4,000 \\
17.79 \\
\end{array}$ & \\
\hline P3257 & $\begin{array}{c}32 " 1 \\
812.8\end{array}$ & $\begin{array}{l}527 \\
239\end{array}$ & $\begin{array}{c}2,000 \\
8,90\end{array}$ & $\begin{array}{c}12 \\
304,8\end{array}$ & $\begin{array}{c}2,000 \\
2,976.3\end{array}$ & $\begin{array}{l}\text { Lbs./Ft. } \\
(\mathrm{kg} / \mathrm{m})\end{array}$ \\
\hline P3257A & $\begin{array}{c}36 " \\
914.4\end{array}$ & $\begin{array}{l}616 \\
279\end{array}$ & $\begin{array}{c}2,000 \\
890\end{array}$ & $\begin{array}{c}12 \\
304.8\end{array}$ & $\begin{array}{c}2,000 \\
2,976.3\end{array}$ & $\begin{array}{l}\text { Lbs./Ft. } \\
(\mathrm{kg} / \mathrm{m})\end{array}$ \\
\hline P3258 & $\begin{array}{c}40^{\prime \prime} \\
1,016.0\end{array}$ & $\begin{array}{l}661 \\
300\end{array}$ & $\begin{array}{c}2,000 \\
8.90\end{array}$ & $\begin{array}{c}12 \\
304.8\end{array}$ & $\begin{array}{c}2,000 \\
2,976.3\end{array}$ & $\begin{array}{l}\text { Lbs./Ft. } \\
(\mathrm{kg} / \mathrm{m})\end{array}$ \\
\hline P3259 & $\begin{array}{c}4^{\prime} \\
1,219.2\end{array}$ & $\begin{array}{l}786 \\
357\end{array}$ & $\begin{array}{c}2,000 \\
8,90\end{array}$ & $\begin{array}{c}12 \\
304.8\end{array}$ & $\begin{array}{c}2,000 \\
2,976.3\end{array}$ & $\begin{array}{l}\text { Lbs. } / \mathrm{Ft} \text {, } \\
(\mathrm{kg} / \mathrm{m})\end{array}$ \\
\hline P3260 & $\begin{array}{c}5^{\prime} \\
1,524.0\end{array}$ & $\begin{array}{c}1,003 \\
455\end{array}$ & $\begin{array}{c}2,000 \\
890\end{array}$ & $\begin{array}{c}12 \\
304.8\end{array}$ & $\begin{array}{c}2,000 \\
2,976.3\end{array}$ & $\begin{array}{l}\text { Lbs. } / \mathrm{Ft} \text {. } \\
(\mathrm{kg} / \mathrm{m})\end{array}$ \\
\hline P3261 & $\begin{array}{c}6^{\prime} \\
1,828.8\end{array}$ & $\begin{array}{c}1,173 \\
532\end{array}$ & $\begin{array}{c}2,000 \\
8,90\end{array}$ & $\begin{array}{c}12 \\
304.8\end{array}$ & $\begin{array}{c}2,000 \\
2,976.3\end{array}$ & $\begin{array}{l}\text { Lbs. } / \mathrm{Ft} \text {. } \\
(\mathrm{kg} / \mathrm{m})\end{array}$ \\
\hline P 3262 & $\begin{array}{c}7^{\prime} \\
2,133.6\end{array}$ & $\begin{array}{l}1,390 \\
630\end{array}$ & $\begin{array}{c}2,000 \\
8.90\end{array}$ & $\begin{array}{c}12 \\
304.8\end{array}$ & $\begin{array}{c}2,000 \\
2,976.3\end{array}$ & $\begin{array}{l}\text { Lbs./Ft. } \\
(\mathrm{kg} / \mathrm{m})\end{array}$ \\
\hline P3263 & $\begin{array}{c}8^{\prime} \\
2,438.4\end{array}$ & $\begin{array}{c}1,560 \\
708\end{array}$ & $\begin{array}{c}2,000 \\
8,90\end{array}$ & $\begin{array}{c}12 \\
304.8\end{array}$ & $\begin{array}{c}2,000 \\
2,976.3\end{array}$ & $\begin{array}{l}\text { Lbs. } . F t . \\
(\mathrm{kg} / \mathrm{m})\end{array}$ \\
\hline P3264 & $\begin{array}{c}9^{\prime} \\
2,743.2\end{array}$ & $\begin{array}{c}1,741 \\
790\end{array}$ & $\begin{array}{c}2,000 \\
890\end{array}$ & $\begin{array}{c}12 \\
304.8\end{array}$ & $\begin{array}{c}2,000 \\
2,976.3\end{array}$ & $\begin{array}{l}\text { Lbs/Ft. } \\
(\mathrm{kg} / \mathrm{m})\end{array}$ \\
\hline P 3265 & $\begin{array}{c}10^{\prime} \\
3,048.0\end{array}$ & $\begin{array}{c}1,947 \\
883\end{array}$ & $\begin{array}{c}2,000 \\
8,90\end{array}$ & $\begin{array}{c}12 \\
304.8\end{array}$ & $\begin{array}{c}2,000 \\
2,976.3\end{array}$ & $\begin{array}{l}\text { Lbs./Ft. } \\
(\mathrm{kg} / \mathrm{m})\end{array}$ \\
\hline P3266 & $\begin{array}{c}12^{\prime} \\
3.657 .6\end{array}$ & $\begin{array}{l}2,334 \\
1,059\end{array}$ & $\begin{array}{c}2,000 \\
8,90\end{array}$ & $\begin{array}{c}12 \\
304.8\end{array}$ & $\begin{array}{c}2,000 \\
2,976.3\end{array}$ & $\begin{array}{l}\text { Lbs. Ft. } \\
(\mathrm{kg} / \mathrm{m})\end{array}$ \\
\hline P3267 & $\begin{array}{c}14^{\prime} \\
4,267.2\end{array}$ & $\begin{array}{l}2,717 \\
1,232\end{array}$ & $\begin{array}{c}2,000 \\
890\end{array}$ & $\begin{array}{c}12 \\
304.8\end{array}$ & $\begin{array}{c}2,000 \\
2,976.3\end{array}$ & $\begin{array}{l}\text { Lbs./Ft. } \\
(\mathrm{kg} / \mathrm{m})\end{array}$ \\
\hline P3268 & $\begin{array}{c}16^{1} \\
4,876.8\end{array}$ & $\begin{array}{l}3,116 \\
1,413\end{array}$ & $\begin{array}{c}2,000 \\
890\end{array}$ & $\begin{array}{c}12 \\
304.8\end{array}$ & $\begin{array}{c}2,000 \\
2,976.3\end{array}$ & $\begin{array}{l}\text { Lbs./Ft. } \\
(\mathrm{kg} / \mathrm{m})\end{array}$ \\
\hline P3269 & $\begin{array}{c}18^{\prime} \\
5,486.4\end{array}$ & $\begin{array}{l}3,530 \\
1,601\end{array}$ & $\begin{array}{c}2,000 \\
8,90\end{array}$ & $\begin{array}{c}12 \\
304.8\end{array}$ & $\begin{array}{c}2,000 \\
2,976.3\end{array}$ & $\begin{array}{l}\text { Lbs./Ft. } \\
(\mathrm{kg} / \mathrm{m})\end{array}$ \\
\hline P $3270^{*}$ & $\begin{array}{c}20^{\prime} \\
6,096,0\end{array}$ & $\begin{array}{l}3,882 \\
1,761\end{array}$ & $\begin{array}{c}2,000 \\
8,90\end{array}$ & $\begin{array}{c}12 \\
304.8\end{array}$ & $\begin{array}{c}2,000 \\
2,976.3\end{array}$ & $\begin{array}{l}\text { Lbs./Ft. } \\
(\mathrm{kg} / \mathrm{m})\end{array}$ \\
\hline
\end{tabular}




\subsection{Analysis and Calculation Guidelines}

Stand designs are often re-used within the Accelerator Complex and sometimes original (or unique) designs are necessary. In either case, before proceeding with a design, initial stress calculations are required. Primary stress and deflection estimates will indicate if a support is adequate or if reinforcement is needed. Weldments are another important consideration regarding stress evaluation.

The basic characteristic of primary stress is that it is not self-limiting, and failure, or at least gross distortion, can occur from one application of the loading. Primary stress is stress caused by the application of mechanical pressure, forces, and moments. Thermal stresses are not primary stresses.

Secondary stress is caused by the constraint of adjacent parts or by self-constraint of the structure, and yielding can cause the source of the stress to be eliminated. One load cycle can cause local yielding and stress redistribution but generally does not result in failure or gross distortion. This document focuses on the primary stresses within the support design.

Allowable stress limits for structural members, welds, and hardware are provided by the American Institute of Steel Construction (AISC) Manual of Steel Construction, Allowable Stress Design ${ }^{1}$. The maximum primary stress shall be less than $0.6 F_{y}$ (in bending or tension), $0.4 F_{y}$ (in shear), where the Tensile Yield Strength $\left(F_{\mathrm{y}}\right)$ for A-500 structural steel is $46 \mathrm{Ksi}$ and for A-36 steel it is $36 \mathrm{Ksi}$.

\section{Stresses in Beams}

Primary stresses within structures may be determined by considering a simple supported beam. This is an effective way to initially understand the stresses present for a given design. As the design progresses, a more detailed analysis may be considered which would include secondary stresses.

\section{Normal Stress}

A normal stress is a stress that occurs when a member is loaded by an axial force. The value of the normal force for any prismatic section is simply the force divided by the cross sectional area:

$$
\begin{gathered}
\sigma=\frac{P}{A} \\
\sigma-\text { Normal Stress } \\
\text { P-Axial Force } \\
\text { A- Cross Sectional Area }
\end{gathered}
$$


A normal stress will occur when a member is placed in tension or compression. Examples of members experiencing pure normal forces would include columns, collar ties, support rods, etc.

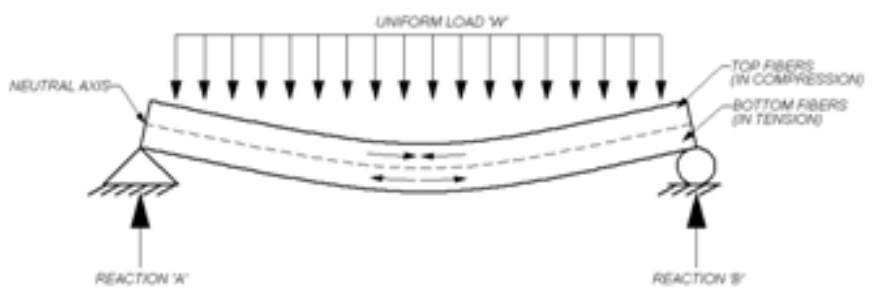

Figure 1-Beam diagram

When a member is being loaded similar to that in Figure 1, bending stress (or flexure stress) will result. Bending stress is a more specific type of normal stress. When a beam experiences load as shown in Figure 1, the top fibers of the beam undergo a normal compressive stress. The stress at the horizontal plane of the neutral axis is zero. The bottom fibers of the beam undergo a normal tensile stress. It can be concluded therefore that the value of the bending stress will vary linearly with distance from the neutral axis.

$$
\begin{gathered}
\sigma_{b}=\frac{M y}{I} \\
\sigma_{b}-\text { Bending stress } \\
M-\text { Calculated bending moment } \\
y-\text { Vertical distance away from the neutral axis } \\
I-\text { Moment of inertia around the neutral axis }
\end{gathered}
$$

Calculating the maximum bending stress is crucial for determining the adequacy of beams and longitudinal girders and stand members.

\section{Shear Stress}

Flexural or bending stress is a result of load applied perpendicular to a member. Shear stress however results when a load is applied parallel to an area. Figure 1 shows that both bending and shear stresses will develop. As in bending stress, shear stress will vary across the cross sectional area. 


$$
\begin{gathered}
\tau=\frac{Q V}{I b} \\
\tau \text { - Shear Stress } \\
Q-\text { Calculated statical moment } \\
V-\text { Calculated shear at specific section } \\
I-\text { Moment of inertia around the neutral axis } \\
b-\text { Width of beam at depth of specific section }
\end{gathered}
$$

Calculating the maximum shear stress is crucial for determining the adequacy of beams and longitudinal girders and stand members. Or simply $\tau=F / A$, where $F$ is the shearing force and $A$ is the cross-sectional area.

A few examples for different situations regarding beams is given in Figures 2, 3, 4 and 5 with the relative equations needed to estimate reactions, moments and deflections.

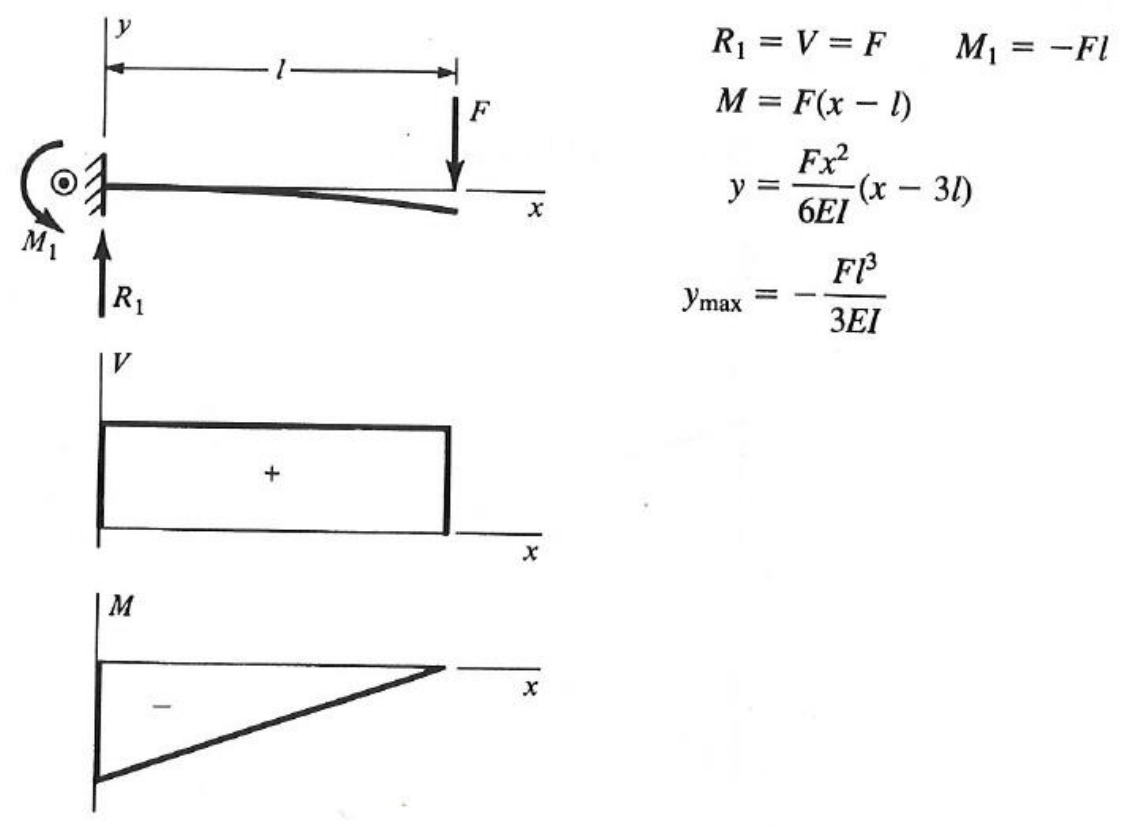

Figure 2: Cantilever beam (end loading) ${ }^{2}$. 


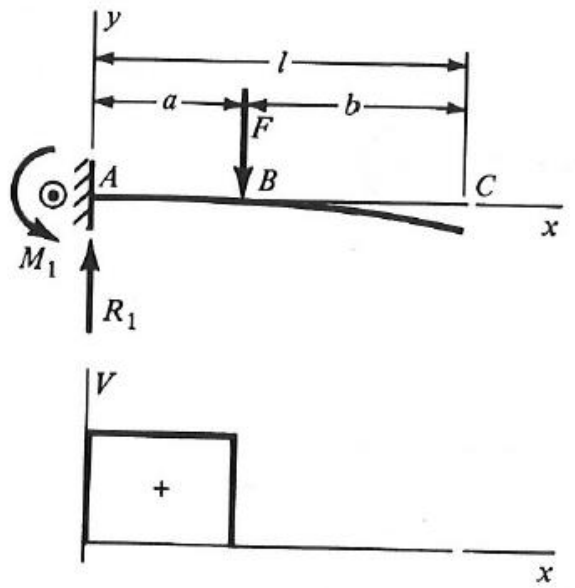

$$
\begin{aligned}
R_{1} & =V=F \quad M_{1}=-F a \\
M_{A B} & =F(x-a) \quad M_{B C}=0 \\
y_{A B} & =\frac{F x^{2}}{6 E I}(x-3 a) \\
y_{B C} & =\frac{F a^{2}}{6 E I}(a-3 x) \\
y_{\max } & =\frac{F a^{2}}{6 E I}(a-3 l)
\end{aligned}
$$

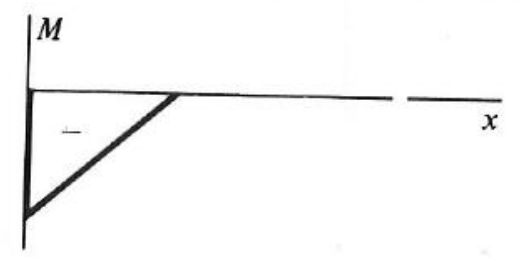

Figure 3: Cantilever beam (intermediate loading) ${ }^{2}$.

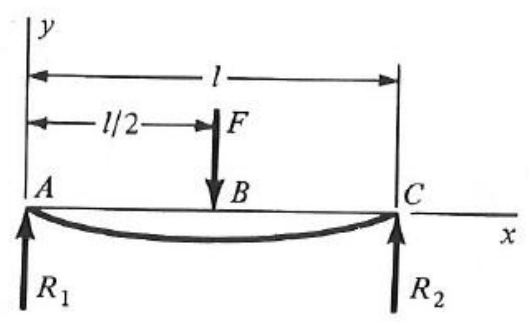

$$
\begin{aligned}
R_{1} & =R_{2}=\frac{F}{2} \quad V_{A B}=R_{1} \\
V_{A B} & =R_{1} \quad V_{B C}=-R_{2} \\
M_{A B} & =\frac{F x}{2} \quad M_{B C}=\frac{F}{2}(l-x) \\
y_{A B} & =\frac{F x}{48 E I}\left(4 x^{2}-3 l^{2}\right) \\
y_{\max } & =-\frac{F l^{3}}{48 E I}
\end{aligned}
$$

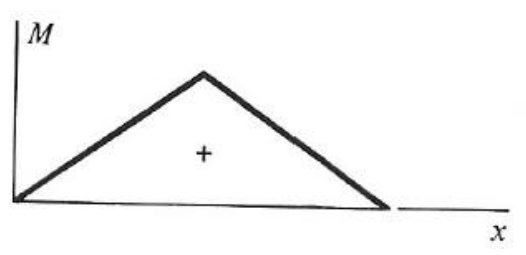

Figure 4: Simple supported beam (center loading) ${ }^{2}$. 


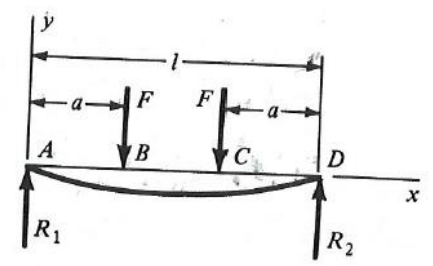

$$
\begin{aligned}
R_{1} & =R_{2}=F \quad V_{A B}=F \quad V_{B C}=0 \\
V_{C D} & =-F \\
M_{A B} & =F x \quad M_{B C}=F a \quad M_{C D}=F(l-x) \\
y_{A B} & =\frac{F x}{6 E I}\left(x^{2}+3 a^{2}-3 l a\right) \\
y_{B C} & =\frac{F a}{6 E I}\left(3 x^{2}+a^{2}-3 l x\right) \\
y_{\max } & =\frac{F a}{24 E I}\left(4 a^{2}-3 l^{2}\right)
\end{aligned}
$$
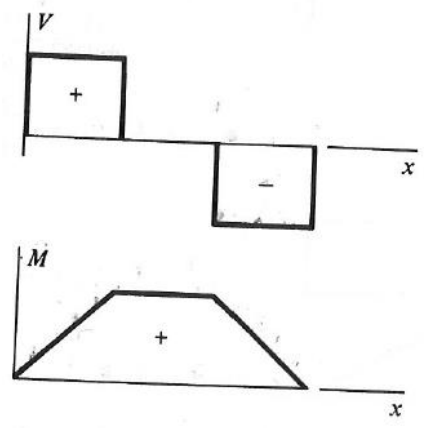

Figure 5: Simple supported beam (twin loading) ${ }^{2}$.

\section{Weldments}

Stresses within butt (with V-groove weld prep) and fillet welds may be estimated using a simplification of the weld's geometry as a line (along the weld path). Bending properties of fillet welds are found in Figures 6 and 7. The primary concern is shear in welds and secondary shear or torsion (produced by bending).

Shear stresses found in a weld are estimated by again applying $\tau=F / A$. The area used is given in either Figure 6 or 7 , depending on the weldment geometry.

Bending stresses within a weld are estimated by again applying, $\sigma_{b}=M(y) / I$ and this basic expression may be modified to include the geometry parameters needed to apply the theory to welds represented as lines. Simply substitute $\mathrm{I}=0.707(\mathrm{~h})\left(\mathrm{I}_{\mathrm{u}}\right)$ and apply the relevant expression given in either Figure 6 or 7 . Properties of welding rod for allowable stress estimation is provided by AISC $^{1}$ or a few examples are given in Figure $8^{2}$. 


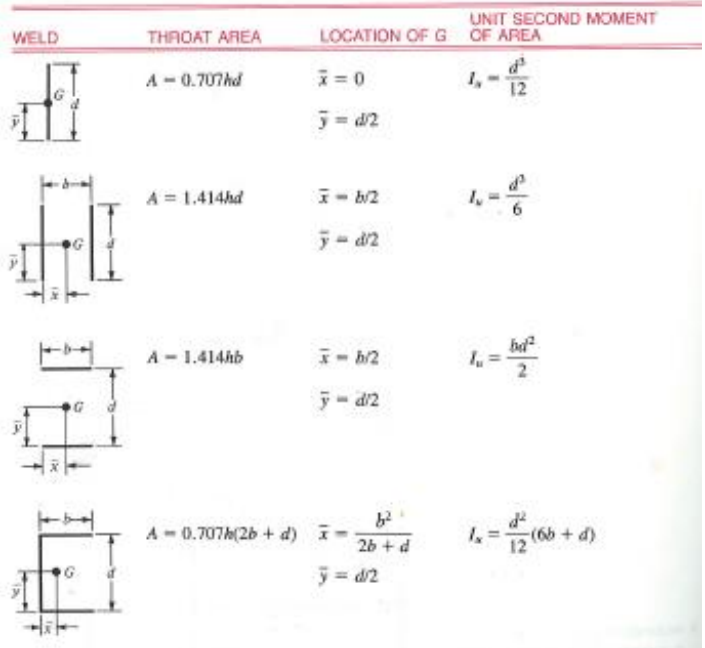

Figure 6: Bending properties of fillet welds (part 1$)^{2}$.

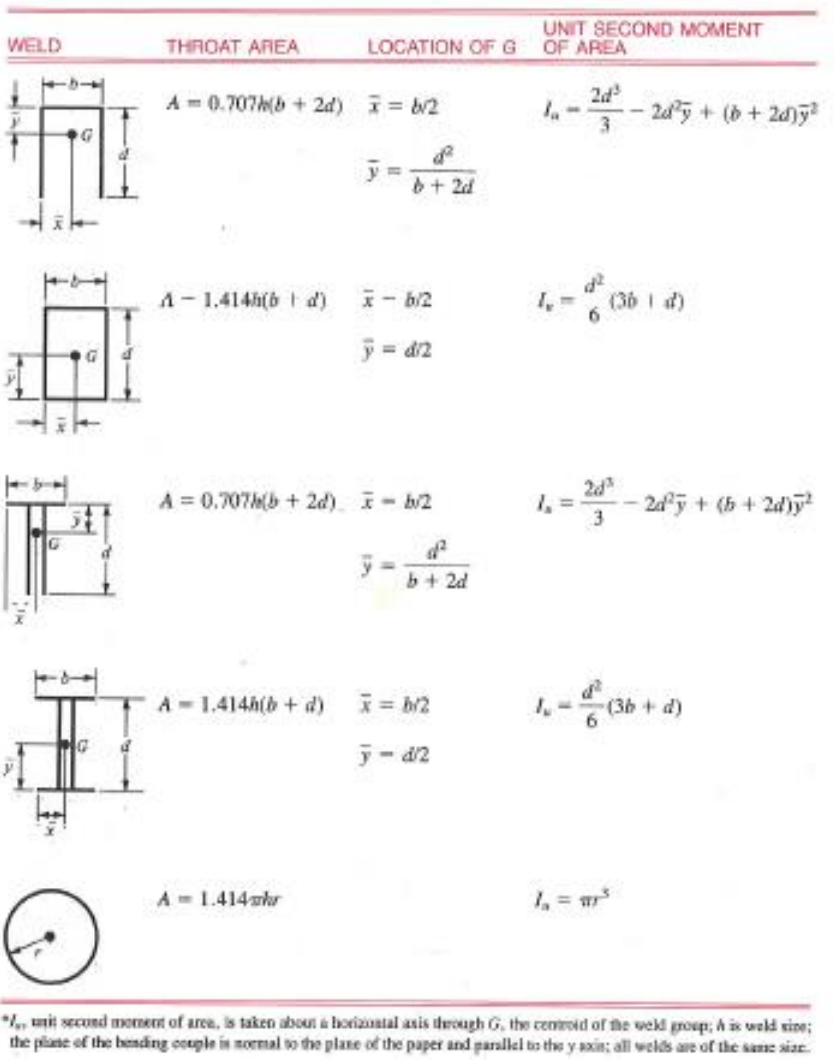

Figure 7: Bending properties of fillet welds (part 2$)^{2}$. 


\begin{tabular}{|c|c|c|c|}
\hline $\begin{array}{l}\text { AWS ELECTRODE } \\
\text { NUMBER }\end{array}$ & $\begin{array}{c}\text { TENGILE STAENGTH, } \\
\text { kgi }\langle\mathrm{MPa}\rangle\end{array}$ & $\begin{array}{l}\text { YIELD STAENOTH. } \\
\text { kpai (MPa) }\end{array}$ & $\begin{array}{l}\text { PEACENT } \\
\text { ELONGATION }\end{array}$ \\
\hline $\mathrm{E} 60 \mathrm{kx}$ & $62(427)$ & 50 (345) & $17-25$ \\
\hline$E 70 \times x$ & $70(482)$ & 57 (393) & 22 \\
\hline E80xx & 80 (551) & $67(462)$ & 19 \\
\hline E90xx & $90(620)$ & $77(531)$ & $14-17$ \\
\hline E100xx & $100(689)$ & $87(600)$ & $13-16$ \\
\hline E120xx & $120(827)$ & $107(737)$ & 14 \\
\hline
\end{tabular}

Figure 8: Minimum weld-metal properties².

I would recommend you add the table that shows torsional properties of welds as well, where $\mathrm{I}=.707(\mathrm{~h})(\mathrm{lu})$ for bending is replaced with $\mathrm{J}=.707(\mathrm{~h})(\mathrm{Ju})$ for torsion. The bending equation does not change. The table will just list the Ju per weld pattern.

\section{References}

[1] American Institute of Steel Construction, "Manual of Steel Construction - Allowable Stress Design," $9^{\text {th }}$ Edition, 1989.

[2] Shigley, J. and C. Mischke, “Mechanical Engineering Design," Fifth Edition, 1989. 